\title{
LA OBLIGACIÓN AUT DEDERE AUT IUDICARE Y SU CUMPLIMIENTO EN ESPAÑA*
}

\author{
Esperanza ORIHUEla CALATAYUd \\ Catedrática de Derecho internacional público y relaciones internacionales \\ Universidad de Murcia
}

SUMARIO: 1. INTRODUCCIÓN.-2. LA OBLIGACIÓN AUT DEDERE AUT IUDICARE EN EL DERECHO INTERNACIONAL.-2.1. Su incorporación en tratados internacionales.-2.2. La obligación aut dedere aut iudicare y el Derecho internacional general.-3. LA OBLIGACIÓN AUT DEDERE AUT IUDICARE Y EL DERECHO ESPAÑOL.-3.1. Las obligaciones derivadas de la regla aut dedere aut iudicare y la regulación prevista en la LOPJ.3.2. Propuestas de mejora que eviten el incumplimiento de la obligación aut dedere aut iudicare.-4. CONCLUSIÓN.

\section{INTRODUCCIÓN}

La obligación de entregar o juzgar (aut dedere aut iudicare) constituye uno de los pilares en los que se apoya la lucha contra la impunidad de quienes cometen crímenes internacionales ${ }^{1}$. Su finalidad consiste en garantizar la persecución universal de los presuntos responsables de la comisión de crímenes internacionales o de delitos de trascendencia internacional y, por ello, ha sido incorporada sistemáticamente en los tratados multilaterales auspiciados por la Organización de las Naciones Unidas (ONU) con la finalidad de hacer efectiva la prevención y sanción de los citados crímenes y delitos.

La trascendencia e importancia del tema es tal que la Comisión de Derecho Internacional (CDI) le ha dedicado su atención en la última década ${ }^{2}$. En

* El presente trabajo se enmarca en el proyecto de investigación DER-2012-34913 «Crímenes internacionales y justicia penal: principales desafíos», financiado por el Ministerio de Economía y Competitividad.

1 La importancia de esta obligación en la cooperación internacional destinada a hacer efectiva la lucha contra la impunidad ya quedó reconocida en la época de Hugo Grocio quien enunció el principio aut dedere aut punire. Su formulación actual, aut dedere aut iudicare, resulta más adecuada y conforme con los estándares derivados del Estado de Derecho y el respeto de los derechos humanos.

${ }^{2}$ El tratamiento de la regla aut dedere aut iudiciare no era nuevo para la CDI ya que cabe considerar, como indica la propia Comisión, que la obligación de extraditar o juzgar estuvo englobada dentro 
su quincuagésimo séptimo periodo de sesiones (2005), la CDI decidió incluir «la obligación de extraditar o juzgar (aut dedere aut judicare)» en su programa de trabajo y nombró Relator Especial a Zdzislaw Galicki, quien presentó cuatro informes ${ }^{3}$ a la Comisión. Su examen concluyó en su sexagésimo sexto periodo de sesiones (2014) con la aprobación del informe final sobre el tema «La obligación de extraditar o juzgar (aut dedere aut judicare)» que pretende servir de guía útil para los Estados ${ }^{4}$.

Aunque su genérica formulación parte de la premisa del interés de un Estado conectado con el crimen de enjuiciar a los presuntos responsables que se encuentran en el territorio de otro Estado al que solicita la extradición ${ }^{5}$, la redacción de las cláusulas convencionales resulta heterogénea y estas no siempre condicionan la obligación de enjuiciar a la existencia de una previa solicitud de extradición.

La sistemática omisión que los ordenamientos internos de los Estados, en particular del español, hacen de la competencia de los tribunales estatales para actuar en la condición de iudex aprehensionis ha provocado que su cumplimiento se haya canalizado generalmente a través del principio de universalidad ${ }^{6}$. Ahora bien, no se debe confundir el cumplimiento de la obligación aut dedere aut iudicare con el ejercicio de la jurisdicción universal como si se tratara de la misma cosa, ni considerar que esta se reduzca al enjuiciamiento cuando el presunto responsable se encuentre en España.

El objeto de este trabajo consiste en analizar el contenido y carácter de la obligación internacional que se deriva de la regla aut dedere aut iudicare; determinar si nuestro ordenamiento interno, en particular nuestra Ley Orgánica del Poder Judicial (LOPJ), contiene una regulación adecuada para garantizar su cumplimiento, y, de ser necesario, hacer propuestas de mejora de la legislación española para hacer posible el cumplimiento de nuestras obligaciones internacionales. Para ello analizaré en primer lugar los tratados internacionales que la han incorporado y de los que España es parte; su contenido, y la posibilidad de que la misma haya adquirido el carácter

de la «Jurisdicción con respecto a delitos cometidos fuera del territorio nacional», que figuraba en la lista provisional de catorce temas seleccionados en el primer periodo de sesiones de la Comisión en 1949 y fue abordado al hilo de la elaboración del Proyecto de Código de crímenes contra la paz y seguridad de la humanidad de 1996, Informe de la Comisión de Derecho Internacional sobre la labor realizada en su 66. periodo de sesiones, del 5 de mayo al 6 de junio y del 7 de julio al 8 de agosto de 2014, Asamblea General. Documentos oficiales. 66. ${ }^{\circ}$ periodo de sesiones, Suplemento núm. 10, (A/69/10), Capítulo VI: La obligación de extraditar o juzgar (aut dedere aut judicare), p. 153.

3 Véase Informe preliminar, de 7 de junio de 2006 (A/CN.4/571); Segundo informe, de 11 de junio de 2007 (A/CN.4/585); Tercer informe, de 10 de junio de 2008 (A/CN.4/603), y Cuarto informe, de 31 de mayo de 2011 (A/CN.4/648).

4 Véase Informe de la Comisión de Derecho internacional sobre la labor realizada en su $66 .^{\circ}$ periodo de sesiones (A/69/10), cit., nota 2, párrs. 57-64.

5 Véase Remiro Brotons, A., Derecho Internacional. Curso General, Valencia, Tirant lo Blanch, 2010, p. 824.

6 Sobre esta cuestión véase ORIHUela Calatayud, E., La jurisdicción universal en España. Discurso leído el 27 de enero de 2016 en el acto de recepción como Académica de Número de la Real Academia de Legislación y Jurisprudencia de la Región de Murcia, Murcia, 2016, p. 126. 
de norma consuetudinaria. Detalladas estas cuestiones, identificaré aquellos delitos que nuestro país se ha obligado a enjuiciar si el presunto culpable se encuentra en España y examinaré la regulación establecida en la LOPJ con la finalidad de determinar si la misma es coherente con dichas obligaciones o si presenta deficiencias y, en este caso, cómo podrían superarse.

\section{LA OBLIGACIÓN AUT DEDERE AUT IUDICARE EN EL DERECHO INTERNACIONAL}

\subsection{Su incorporación en tratados internacionales}

Desde que el Convenio de Ginebra, de 20 de abril de 1929, sobre la represión de la falsificación de moneda ${ }^{7}$ incluyera dos disposiciones que combinan la extradición y el enjuiciamiento ${ }^{8}$, la inmensa mayoría de los tratados internacionales de alcance universal destinados a la prevención y sanción de crímenes internacionales y de delitos de trascendencia internacional ${ }^{9}$ contie- $^{2}$ nen disposiciones en las que se recoge la obligación de extraditar o juzgar. La excepción nos la brindan la Convención de Nueva York, de 9 de diciembre de 1948, para la prevención y la sanción del delito del genocidio ${ }^{10}$, que confía el enjuiciamiento a los tribunales del Estado en cuyo territorio se cometiera el crimen o a un tribunal penal competente ${ }^{11}$, y el Convenio de Tokio, de 14 de septiembre de 1963, sobre infracciones cometidas a bordo de aeronaves ${ }^{12}$, cuyo texto no incorpora la obligación de establecer la jurisdicción respecto de aquellos supuestos en los que el presunto delincuente se encuentre en su

7 Gaceta de Madrid, de 8 de abril de 1931.

8 Véanse arts. 8 y 9.

9 Sobre las diferentes posiciones en torno al término crimen internacional y la posible clasificación de estos, véase ad. ex., BASsiouni, M. Ch., «International Crimes: The Ratione materiae of International Criminal Law», en Bassiouni, M. Ch., International Criminal Law, vol. 1, 3. a ed., Leiden, Martinus Nijhoff, 2008, pp. 129-203; SÁNCHEZ LEgIDO, A., Jurisdicción universal penal y Derecho internacional, Valencia, Tirant lo Blanch, 2004, pp. 57-65; TERJE, E., The concept of universal crimes in international law, Oslo, EPublisher, 2012. También es posible encontrar referencias a las distintas posiciones sobre el alcance del término crimen internacional o a la forma en que lo entienden los autores en algunas obras generales relacionadas con el Derecho internacional penal. En este sentido, véase BoISTER, N., An Introduction to Transnational Criminal Law, Oxford, Oxford University Press, 2012, pp. 3-8; CASSESE, A., International Criminal Law, Oxford, Oxford University Press, 2003, pp. 23-25; CrYer, R., Friman, H., Robinson, D. y Wilmshurst, E., An Introduction to International Criminal Law and Procedure, 3. ${ }^{\mathrm{a}}$ ed., Cambridge, Cambridge University Press, 2014, pp. 3-8; WerLe, G., Principles of International Criminal Law, La Haya, Asser Press, 2005, pp. 25-27.

10 BOE núm. 34, de 8 de febrero de 1969.

11 En el asunto de la Aplicación del Convenio para la prevención y sanción del delito de genocidio (Bosnia y Herzegovina c. Serbia y Montenegro), la CIJ puso de manifiesto que la obligación de enjuiciar este crimen solo afecta al Estado en cuyo territorio se hubiera cometido, CIJ, Reports, 2007, párr. 442.

12 BOE núm. 308, de 25 de diciembre de 1969. Este convenio ha sido modificado por el Protocolo de 4 de abril de 2014 que todavía no ha entrado en vigor y al que nuestro país aún no ha manifestado el consentimiento. Véase http://www.icao.int/secretariat/legal/Status\%20of\%20individual\%20States/ spain_es.pdf (consultada el 13 de junio de 2016). 
territorio y no se conceda la extradición ni la derivada de la regla aut dedere aut indicare ${ }^{13}$.

Tomando como referencia los tratados adoptados después de la creación de las Naciones Unidas, de vocación universal y en los que España es parte, la primera incorporación de esta obligación la encontramos en los cuatro Convenios de Ginebra, de 12 de agosto de 1949, núcleo esencial del Derecho internacional humanitario, que imponen a las partes la obligación de enjuiciar a las personas responsables de haber cometido infracciones graves de los mismos y en los que se ofrece a estos Estados la posibilidad de entregarlas a otra parte interesada en la persecución siempre que esta haya formulado contra las mismas cargos suficientes ${ }^{14}$; obligación que resulta aplicable a las infracciones del Protocolo I, de 8 de junio de 1977, adicional a los Convenios de Ginebra de 12 de agosto de 1949, relativo a la protección de las víctimas de los conflictos armados internacionales ${ }^{15}$.

Con posterioridad a estos, la Convención, de 16 de diciembre de 1970, sobre represión del apoderamiento ilícito de aeronaves ${ }^{16}$ incorporó una disposición en la que se prevé que el Estado parte en cuyo territorio se encuentre el presunto delincuente, si no procede a la extradición, someterá el caso a sus autoridades a efectos de enjuiciamiento (art. 7) y, para garantizar su cumplimiento, impone a las partes el deber de establecer su jurisdicción en aquellos casos en los que el delincuente se encuentre en su territorio y no conceda la extradición (art. 4.2). Posiblemente los negociadores de la Convención de La Haya no fueran conscientes de su capacidad persuasiva, pero el art. 7 se convirtió en inspiración para los negociadores de otros tratados que copiaron, con pequeñas diferencias, la denominada fórmula de La Haya.

Estos avances convencionales no se limitaron a cuestiones relacionadas con la seguridad de la aviación civil ${ }^{17}$, sino que se dirigieron también a las

13 El convenio faculta al Estado en cuyo territorio se encuentre el delincuente a su detención a los efectos del inicio del procedimiento penal o de la extradición, si las circunstancias lo justifican y se dan las condiciones requeridas para ello (art. 13), por lo que no existe una obligación de enjuiciar en todo caso. El enjuiciamiento y la extradición parecen constituir opciones alternativas de carácter facultativo que el Estado puede barajar y, además, puede estimular la solicitud de extradición ya que el convenio obliga al Estado que procede a la detención a comunicar esta circunstancia a los Estados interesados, entre los que se encuentran el de la matrícula de la aeronave y el de la nacionalidad de la persona detenida.

14 Véase art. 49 del Convenio (I) para mejorar la suerte de los heridos y enfermos de las fuerzas armadas en campaña, BOE de 23 de agosto de 1952; art. 50 del Convenio (II) para mejorar la suerte de los heridos, enfermos y náufragos de las fuerzas armadas en el mar, $B O E$ de 26 de agosto de 1952; art. 129 del Convenio (III) relativo al trato de los prisioneros de guerra, $B O E$ de 5 de septiembre de 1952, y art. 146 del Convenio (IV) relativo a la protección de las personas civiles en tiempo de guerra, $B O E$ de 2 de septiembre de 1952.

15 En virtud de lo establecido en su art. 85.1, BOE núm. 177, de 26 de julio de 1989. Este tratado, al regular las cuestiones relativas a la asistencia judicial en materia penal, insta a las partes a tomar debidamente en consideración la solicitud presentada por el Estado en cuyo territorio se haya cometido la infracción alegada (art. 88.2).

16 BOE núm. 13, de 15 de enero de 1973.

17 Convenio de Montreal, de 23 de septiembre de 1971, sobre represión de actos ilícitos contra la seguridad de la aviación (art. 7), BOE núm. 9, de 10 de enero de 1974, complementado por el Protocolo 
vinculadas con la represión de ilícitos relacionados con la seguridad de la navegación marítima y la seguridad de las plataformas fijas situadas en la plataforma continental ${ }^{18}$; la seguridad de los materiales nucleares ${ }^{19}$; los cometidos contra las personas internacionalmente protegidas y el personal de las Naciones Unidas ${ }^{20}$, los de terrorismo ${ }^{21} \mathrm{o}$, incluso, relacionados con la prevención y sanción de conductas que suponen un atentado contra los derechos humanos, como la tortura y la desaparición forzada de personas ${ }^{22}$, o los crímenes de guerra ${ }^{23}$.

Ahora bien, no todos los convenios relacionados con la delincuencia internacional han incorporado la obligación de extraditar o juzgar bajo la denominada fórmula de La Haya, sino que han seguido un modelo diferente ${ }^{24}$. Tomando como ejemplo el Convenio de Ginebra, de 20 de abril de 1929, sobre represión de la falsificación de moneda ${ }^{25}$, cuyo art. 9 advertía que la obligación de persecución se subordinará a la condición de que la extradición haya sido solicitada y se haya denegado, los convenios de Naciones Unidas

de Montreal, de 24 de febrero de 1988, para la represión de actos de violencia ilícitos cometidos en aeropuertos que presten servicios a la aviación civil, complementario del Convenio para la represión de actos ilícitos contra la seguridad de la aviación civil, BOE núm. 56, de 5 de marzo de 1992; Convenio, de 10 de septiembre de 2010, para la represión de actos ilícitos relacionados con la aviación civil internacional, llamado a sustituir al Convenio de Montreal de 1971 y al Protocolo de 1988 (art. 10). Este convenio aún no ha entrado en vigor ni ha sido ratificado. Véase http://www.icao.int/secretariat/legal/ Status\%20of\%20individual\%20States/spain_es.pdf (consultada el 13 de junio de 2016).

18 Convención de Roma, de 10 de marzo de 1988, para la represión de los ilícitos contra la seguridad de la navegación marítima (art. 10.1), BOE núm. 99, de 24 de abril de 1992, y Protocolo de Roma, de 10 de marzo de 1988, para la represión de ilícitos contra la seguridad de las plataformas fijas situadas en la plataforma continental, BOE núm. 99, de 24 de abril de 1992. Estos textos han sido modificados por sendos Protocolos de 14 de octubre de 2005 (BOE núm. 170, de 14 de julio de 2010, en el que se puede consultar el texto refundido del convenio). En virtud de lo establecido en el art. 1, al Protocolo relacionado con la seguridad de las plataformas se le aplica lo dispuesto en el art. 10 de la Convención de Roma citada anteriormente que es el que recoge la obligación aut dedere aut iudicare.

19 Convención de Viena, de 3 de marzo de 1980, sobre protección física de los materiales nucleares (art. 10), BOE núm. 256, de 25 de octubre de 1991.

20 Convención de Nueva York, de 14 de diciembre de 1973, sobre la prevención y el castigo de delitos contra personas internacionalmente protegidas, inclusive los agentes diplomáticos (art. 7), $B O E$ núm. 33, de 7 de febrero de 1986; Convención de las Naciones Unidas, de 9 de diciembre de 1994, sobre seguridad del personal de las Naciones Unidas y del personal asociado (art. 14), BOE núm. 124, de 25 de mayo de 1999.

21 Convención de las Naciones Unidas, de 15 de diciembre de 1997, para la represión de los atentados terroristas con bombas (art. 8.1), BOE núm. 140, de 12 de junio de 2001; Convenio de Nueva York, de 9 de diciembre de 1999, para la represión de la financiación del terrorismo (art. 10.1), BOE núm. 123, de 23 de mayo de 2002; Convención, de 13 de abril de 2005, para la supresión de actos de terrorismo nuclear (art. 11.1), BOE núm. 172, de 19 de julio de 2007.

22 Convención de las Naciones Unidas, de 10 de diciembre de 1984, contra la tortura y otras penas o tratos crueles o degradantes (art. 7.1), BOE núm. 268, de 9 de noviembre de 1987; Convención, de 20 de diciembre de 2006, sobre protección de todas las personas contra las desapariciones forzadas, $B O E$ núm. 42, de 18 de febrero de 2011, a los que cabe añadir la Convención de Nueva York, de 17 de diciembre de 1979, contra la toma de rehenes (art. 8), BOE núm. 162, de 7 de julio de 1984.

${ }^{23}$ A esta fórmula se adaptaron los negociadores del Protocolo II, de 26 de marzo de 1999, de la Convención de La Haya, de 12 de agosto de 1954, sobre la protección de los bienes culturales en caso de conflicto armado (art. 17.1), BOE núm. 77, de 30 de marzo de 2004.

${ }^{24}$ Sobre las diferencias de estas cláusulas véase Orinuela Calatayud, E., op. cit., nota 6, pp. 59-72.

25 Cit., nota 7. 
relacionados con el tráfico de drogas, la delincuencia organizada de carácter transnacional y la corrupción incluyeron una disposición en la que la obligación de enjuiciar solo surge cuando se deniega la extradición ${ }^{26}$. Una fórmula que también utilizaron los negociadores del Protocolo, de 25 de mayo de 2000, facultativo de la Convención sobre los derechos del niño, relativo a la venta de niños, la prostitución infantil y la utilización de los niños en la pornografía ${ }^{27}$.

Al igual que hiciera la Convención de La Haya, de 16 de diciembre de 1970, todos estos convenios han acompañado esta obligación de las que imponen a los Estados parte tipificar y sancionar en su ordenamiento interno los comportamientos prohibidos por el convenio y reconocer la competencia de sus tribunales para conocer de estos delitos cuando el presunto culpable se encuentre en su territorio, en coherencia con la fórmula adoptada para referirse a la obligación aut dedere aut iudicare ${ }^{28}$.

26 Véase el art. 36.2.a) iv) del Convenio, de 30 de marzo de 1961, único sobre estupefacientes, $B O E$ núm. 96, de 22 de abril de 1966, modificado por el Protocolo, de 26 de marzo de 1972, BOE núm. 39, de 15 de febrero de 1977; el art. 22.2.a) iv) del Convenio, de 21 de febrero de 1971, sobre sustancias sicotrópicas, BOE núm. 218, de 10 de septiembre de 1976, y el art. 6.9 de la Convención de las Naciones Unidas, de 20 de diciembre de 1988, contra el tráfico ilícito de estupefacientes y sustancias sicotrópicas, $B O E$ núm. 270, de 10 de noviembre de 1990; los arts. 15.3 y 16.10 de la Convención de las Naciones Unidas, de 15 de noviembre de 2000, contra la delincuencia organizada transnacional, $B O E$ núm. 233, de 29 de septiembre de 2003, aplicable a sus Protocolos en virtud de lo establecido en sus arts. 1 (Protocolo, de 15 de noviembre de 2000, para prevenir, reprimir y sancionar la trata de personas, especialmente mujeres y niños que complementa a la Convención de las Naciones Unidas contra la delincuencia organizada transnacional, BOE núm. 296, de 11 de diciembre de 2003; Protocolo, de 15 de noviembre de 2000, contra el tráfico ilícito de migrantes por tierra, mar y aire, que completa la Convención de las Naciones Unidas contra la delincuencia organizada transnacional, BOE núm. 295, de 10 de diciembre de 2003, y Protocolo de Nueva York, de 31 de mayo de 2001, contra la fabricación y el tráfico ilícitos de armas de fuego, sus piezas y componentes y municiones que completa la Convención de las Naciones Unidas contra la delincuencia organizada transnacional, BOE núm. 71, de 23 de marzo de 2007), y el art. 44.11 de la Convención de las Naciones Unidas, de 31 de octubre de 2003, contra la corrupción, BOE núm. 171, de 19 de julio de 2006.

27 BOE núm. 27, de 31 de enero de 2002. En su art. 5.5 se dispone que: «Si se presenta una solicitud de extradición respecto de uno de los delitos a que se refiere el párrafo 1 del art. 3 y el Estado requerido no la concede o no desea concederla en razón de la nacionalidad del autor del delito, ese Estado adoptará las medidas que correspondan para someter el caso a sus autoridades competentes a los efectos del enjuiciamiento».

28 Véanse los arts. 22.1 y 22.2.a) iv) del Convenio, de 21 de febrero de 1971, sobre sustancias sicotrópicas, cit., nota 26; arts. 3 y 5.2 del Convenio de Montreal sobre represión de actos ilícitos contra la seguridad de la aviación, cit., nota 17; arts. 2 y 3.2 de la Convención sobre la prevención y el castigo de delitos contra personas internacionalmente protegidas, cit., nota 20; arts. 2 y 5.2 de la Convención contra la toma de rehenes, cit., nota 22; arts. 7.2 y 8.2 de la Convención sobre protección física de los materiales nucleares, cit., nota 19; arts. 4 y 5.2 de la Convención contra la tortura, cit., nota 22; arts. 5 y 6.4 de la Convención para la represión de los ilícitos contra la seguridad de la navegación marítima y arts. 1 y 3.4 del Protocolo para la represión de ilícitos contra la seguridad de las plataformas fijas situadas en la plataforma continental, cit., nota 18; arts. 3 y 4.2 de la Convención contra el tráfico ilícito de estupefacientes y sustancias sicotrópicas, cit., nota 26; arts. 9.2 y 10.4 de la Convención sobre seguridad del personal de las Naciones Unidas y del personal asociado, cit., nota 20; arts. 4 y 6.4 de la Convención para la represión de los atentados terroristas con bombas, cit., nota 21; art. 15.2 del Protocolo II sobre la protección de los bienes culturales en caso de conflicto armado, cit., nota 22, al igual que los Convenios de Ginebra la competencia de los tribunales de los Estados partes viene conferida por el propio tratado; arts. 4 y 7.4 del Convenio para la represión de la financiación del terrorismo, cit., nota 21; arts. 3 y 4.3 del Protocolo facultativo de la Convención sobre los derechos del niño, relativo a la 
Nos encontramos, por tanto, ante cláusulas que intentan asegurar el enjuiciamiento de los criminales imponiendo a las partes una obligación que puede cumplirse mediante el enjuiciamiento por los tribunales del Estado en cuyo territorio se encuentra el presunto culpable, la extradición o, como ha previsto la Convención, de 20 de diciembre de 2006, sobre protección de todas las personas contra las desapariciones forzadas ${ }^{29}$, mediante su transferencia a una instancia penal internacional; una tercera vía ${ }^{30}$ que debe tenerse en cuenta a la hora de establecer el contenido de futuras disposiciones convencionales relacionadas con la represión de crímenes sobre los que tengan competencia los tribunales penales internacionales ${ }^{31}$.

Resulta evidente que los convenios relacionados con el narcotráfico, la delincuencia organizada de carácter transnacional, la corrupción o la venta de niños, la prostitución infantil y la utilización de los niños en la pornografía han optado por condicionar la obligación de enjuiciar a la previa solicitud de extradición y su posterior denegación. Sin embargo, cuando la cláusula se redacta de la forma en que lo hicieron los Convenios de Ginebra, de 12 de agosto de 1949, o utilizando la denominada fórmula de La Haya, su aplicación puede generar dudas sobre cuál es el momento en el que surge la obligación y/o si esta está condicionada a la solicitud y denegación de la extradición. Una duda que se suscitó en relación con la Convención de las Naciones Unidas, de 10 de diciembre de 1984, contra la tortura y otras penas o tratos crueles o degradantes ${ }^{32}$.

venta de niños, prostitución infantil y utilización de los niños en la pornografía, cit., nota 27; arts. 5, 6, 8 y 15.3 de la Convención contra la delincuencia organizada transnacional, cit., nota 26; arts. 3 y 4.3 del Protocolo para prevenir, reprimir y sancionar la trata de personas, especialmente mujeres y niños, cit., nota 25; arts. 1 y 6 del Protocolo contra el tráfico ilícito de migrantes por tierra, mar y aire, cit., nota 25; arts. 1 y 5 del Protocolo contra la fabricación y el tráfico ilícitos de armas de fuego, sus piezas y componentes y municiones, cit., nota 26; arts. 15-27, 42.3 y 4 de la Convención contra la corrupción, cit., nota 25; arts. 5 y 9.4 de la Convención para la supresión de actos de terrorismo nuclear, cit., nota 21; arts. 4, 7 y 9.2 de la Convención sobre protección de todas las personas contra las desapariciones forzadas, cit., nota 22; arts. 1.5, 3 y 8.3 del Convenio para la represión de actos ilícitos relacionados con la aviación civil internacional, cit., nota 17 .

${ }^{29}$ BOE núm. 42, de 18 de febrero de 2011.

30 De tercera alternativa habla la CDI, véase Informe de la Comisión de Derecho Internacional sobre la labor realizada en su $66 .^{\circ}$ periodo de sesiones (A/69/10), cit., nota 2, p. 166.

31 Esta es la postura que mantiene el Relator Especial para el tema de los crímenes de lesa humanidad, Sean D. Murphy, pues en su Segundo Informe sobre los crímenes de lesa humanidad, de 21 de enero de 2016 (A/CN.4/690) ha incluido un proyecto de art. 9 que bajo la rúbrica aut dedere aut judicare ha redactado de la siguiente forma: «1. Si una persona que presuntamente haya cometido uno de los delitos a los que se hace referencia en el proyecto de artículo 5, párrafos 1 y 2, es hallada en cualquier territorio bajo la jurisdicción o el control de un Estado, ese Estado someterá el asunto a sus autoridades competentes a efectos de enjuiciamiento, salvo que extradite o entregue a la persona a otro Estado o tribunal penal internacional competente. 2. Si el Estado somete el asunto a sus autoridades competentes a efectos de enjuiciamiento, esas autoridades decidirán si proceden al enjuiciamiento y el modo de enjuiciar de la misma manera en que lo harían por cualquier delito común de carácter grave, de acuerdo con la legislación de tal Estado».

32 BOE núm. 268, de 9 de noviembre de 1987. Su art. 7.1 establece: «El Estado Parte en el territorio de cuya jurisdicción sea hallada la persona de la cual se supone que ha cometido cualquiera de los delitos a que se hace referencia en el art. 4, en los supuestos previstos en el art. 5, si no procede a su extradición, someterá el caso a sus autoridades competentes a efectos de enjuiciamiento». 
La queja formulada ante el Comité contra la Tortura (CAT) por algunas víctimas de las torturas efectuadas por agentes del Estado chadiano y de las que se consideraba responsable a Hissène Habré, antiguo Presidente del Chad que se refugió en Senegal tras su derrocamiento en diciembre de 1990, y la controversia surgida entre Bélgica y Senegal a raíz de la negativa del Estado africano a extraditar al presunto culpable al Estado requirente, han permitido clarificar el alcance y carácter de la obligación contenida en el art. 7 de la Convención contra la tortura y, por extensión, de las disposiciones que siguen este modelo ${ }^{33}$.

En su decisión, de 17 de mayo de 2006, el Comité contra la Tortura puso de relieve que la obligación de enjuiciamiento recogida en el art. 7.1 de la Convención no queda a expensas de la existencia de una solicitud de extradición ${ }^{34}$, posición reiterada por la Corte Internacional de Justicia (CIJ) en su Sentencia, de 20 de julio de 2012, en la que advirtió, además, que la extradición, limitada según la propia Convención a los Estados que según sus disposiciones tengan competencia para enjuiciar, es la vía que permite eludir el cumplimiento de la obligación de juzgar ${ }^{35}$.

Si tenemos en cuenta que la finalidad perseguida por estas disposiciones es la de conseguir la persecución universal de los responsables de la comisión de crímenes internacionales o delitos de trascendencia internacional, es necesario advertir que la eficacia de estas disposiciones no es idéntica. Mientras que los Convenios de Ginebra y los tratados que siguen la fórmula de la Haya aseguran la persecución universal al primar la obligación de enjuiciar sobre la de la entrega, la eficacia de las que hacen lo propio con la extradición está condicionada a lo que podemos denominar un dedere frustrado.

33 Sobre la extensión de la interpretación efectuada respecto de la Convención contra la tortura a otros convenios internacionales que contienen cláusulas de este tipo se decanta también el Estudio de la Secretaría de la CDI titulado Examen de las convenciones multilaterales que pueden resultar pertinentes para la labor de la Comisión de Derecho Internacional sobre el tema «La obligación de extraditar o juzgar (aut dedere aut judicare)", de 18 de julio de 2010 (A/CN.4/630), pp. 69-70, párr. 131.

34 En su decisión, el CAT puso de manifiesto que «la obligación de enjuiciar al presunto autor de actos de tortura no depende de la existencia previa de una solicitud de extradición del mismo. Esta alternativa que se ofrece al Estado parte en virtud del art. 7 de la Convención existe solo si se ha formulado efectivamente dicha demanda de extradición, y puesto, por ende, al Estado parte, en la situación de escoger entre $a$ ) proceder a esa extradición o $b$ ) someter el caso a sus propias autoridades judiciales para iniciar la acción penal, ya que la disposición tiene por finalidad evitar la impunidad de todo acto de tortura».

${ }^{35}$ En palabras de la Corte: «Le paragraphe 1 de l'article 7 impose à l'État concerné l'obligation de soumettre l'affaire à ses autorités compétentes pour l'exercice de l'action pénale, indépendamment de l'existence, au préalable, d'une demande d'extradition à l'encontre du suspect [...] En revanche, si l'État sur le territoire duquel se trouve le suspect est saisi d'une demande d'extradition dans l'un des cas prévus par les dispositions de la convention, il peut se libérer de son obligation de poursuivre en faisant droit à la demande d'extradition. Il en résulte que le choix entre l'extradition et l'engagement des poursuites, en vertu de la convention, ne revient pas à mettre les deux éléments de l'alternative sur le même plan. En effet, l'extradition est une option offerte par la convention à l'État, alors que la poursuite est une obligation internationale, prévue par la convention». Véase asunto relativo a las Cuestiones relativas a la obligación de perseguir o extraditar (Bélgica c. Senegal), CIJ, Recueil, 2012, párrs. 94- 95. 


\subsection{La obligación aut dedere aut iudicare y el Derecho internacional general}

La generalizada incorporación de la obligación aut dedere aut iudicare en convenios internacionales ha permitido plantear la cuestión relacionada con el carácter de la norma; esto es, si nos encontramos ante una simple norma convencional cuyo alcance subjetivo queda limitado a los Estados parte en cada uno de los convenios o si cabe considerar que la misma ha trascendido dicho carácter para convertirse en norma consuetudinaria ${ }^{36}$ que obliga a quienes son terceros respecto de los tratados.

La doctrina no mantiene una posición unánime al respecto ${ }^{37}$. Para algunos autores, aunque esta regla se encuentra incluida en numerosos convenios internacionales, resulta todavía prematuro considerar que forme parte del Derecho internacional general y, por tanto, solo ampara actuaciones de los Estados parte en los convenios y respecto de los crímenes a los que acompa$\tilde{n} a^{38}$. En el polo opuesto existen voces que afirman que la máxima aut dedere aut iudicare forma parte del Derecho internacional de carácter consuetudinario ${ }^{39}$ y aún cabe advertir la existencia de una posición intermedia que es la

36 Sobre la posible formación de una norma consuetudinaria que contenga la obligación de extraditar o juzgar, véase el exhaustivo trabajo de Sosa Navarro, M., Aut dedere aut judicare, crimen de lesa humanidad y Corte Penal Internacional, Instituto de Estudios Internacionales y Europeos Francisco de Vitoria, Colección electrónica, núm. 7, 2016.

37 Véase SÁnchez Legido, A., Jurisdicción universal..., op. cit., nota 9, pp. 254-255, y BassiounI, M. Ch. y WiSE, E. M., Aut dedere aut judicare: The Duty to Extradite or Prosecute in International Law, Dordrecht, Martinus Nijhoff, 1995, pp. 20-69, en las que se hace un análisis de las posiciones doctrinales existentes al respecto. Sobre las distintas posiciones doctrinales, véase Mitchell, C., Aut dedere, Aut judicare: The Extradite or Prosecute Clause in International Law, eCahiers, 2009, núm. 2, párrs. 20-85.

38 Posición que en la doctrina española defienden ABAD CASTElos, M., La toma de rehenes como manifestación de terrorismo y el Derecho internacional, Madrid, Ministerio del interior, Secretaría General Técnica, 1997, pp. 153-154 y p. 376, nota 187; ABELLÁN HonRUBIA, V., "La responsabilité internationale de l'individu», R. des C., t. 280, 1999, pp. 249 y 362, y PUEyo LosA, J., «Un nuevo modelo de cooperación internacional en materia penal: entre la justicia universal y la jurisdicción internacional», en ÁLVAREZ GonzÁlez, S. y Remacha y TEJADA, J. R., Cooperación jurídica internacional, Madrid, Colección Escuela Diplomática, 2001, núm. 5, p. 193. Por lo que respecta a la doctrina extranjera, esta es la posición mantenida por CASSESE, A., International Criminal Law, Oxford, Oxford University Press, 2003, p. 301; CrYer, R., Prosecuting International Crimes. Selectivity and the International Criminal Law Regime, Cambridge, Cambridge University Press, 2005, pp. 110-116; MAISON, R., «Les premiers cas d'application des dispositions pénales des Conventions de Genève par les juridictions internes», EJIL, vol. 6, 1995, p. 270, nota 32; PlaCHTA, M., "Contemporary problems of extradition: human rights, grounds for refusal and the principle aut dedere aut judicare», $114^{\text {th }}$ International Training Course, Visiting experts papers, Resource material series, 2001, núm. 27, pp. 64-86, en p. 73; RANDALL, K., «Universal Jurisdiction under International Law», Texas Law Review, 1988, p. 833; RoBERTSON, G., Crimes against Humanity, Nueva York, Penguin, 1999, p. 366; SungA, L., The Emerging System of International Criminal Law, La Haya-Londres-Boston, Kluwer Law International, 1997, pp. 254-255 y 272; Томuschaт, Ch., «La Cristallisation Coutumière», en Ascensio, H., DeCaux, E. y Pellet (eds.), Droit International Penal (2. ${ }^{a}$ ed.), París, Pedone, 2012, p. 29; Weller, M., «On hazards of foreign travel for dictators and other international criminals», International Affairs, vol. 75, 1999, pp. 608-609.

39 Posiblemente sea BAssiouni, M. Ch., el máximo exponente de esta posición doctrinal. Véase en este sentido, International Extradition: United States Law and Practice, 1987, p. 22, y Crimes against Humanity, Dordrecht-Boston-Londres, Martinus Nijhoff, 1992, pp. 499-510. La misma posición mantienen David, E., Principes de droit des conflits armés, Bruselas, Bruylant, 1994, pp. 667-668; ROHT-ARRIA- 
mantenida por quienes consideran que el carácter de Derecho internacional general cabe predicarlo de la misma cuando de represión de crímenes prohibidos por una norma de ius cogens se trate ${ }^{40}$. Divergencias que también alcanzaron a los propios jueces de la CIJ y que quedaron patentes en las opiniones que acompañaron a las decisiones, de 14 de abril de 1992, en las que se pronunciaron sobre la solicitud de medidas cautelares efectuada por Libia en el asunto Lockerbie que enfrentó a dicho país con Estados Unidos y el Reino Unido ${ }^{41}$.

Los tribunales internacionales tampoco ayudan a despejar la incógnita. Mientras la Sala de Apelaciones del Tribunal Penal Internacional para la exYugoslavia (TPIY), en su Sentencia de 29 de octubre de 1997, afirmó que los Estados están obligados por el Derecho consuetudinario a juzgar o extradi$\operatorname{tar}^{42}$, la CIJ ha evitado pronunciarse sobre esta cuestión. En 2012, cuando dictó sentencia en el asunto denominado precisamente Cuestiones relativas a la obligación de juzgar o extraditar que enfrentó a Bélgica contra Senegal, la Corte eludió pronunciarse sobre la existencia de la obligación de persecución universal que incumbiría a Senegal sobre la base del Derecho internacional general y que habría comportado pronunciarse sobre el estatus de Derecho consuetudinario de la máxima aut dedere aut iudicare ${ }^{43}$.

ZA, N., "Nontreaty Sources of an Obligation to Investigate and Prosecute», en RoHT-ArriAZA, N. (ed.), Impunity and Human Rigths in International Law and Practice, Nueva York-Oxford, Oxford University Press, 1995, p. 41. En España esta posición es la mantenida por AlCAIDE FERNÁNDEZ, J., Las actividades terroristas ante el Derecho internacional contemporáneo, Madrid, Tecnos, 2000, pp. 134-136, en relación con el terrorismo.

${ }^{40}$ En este sentido, véase JuRd, N. N., The International Criminal Court and National Courts. A Contentious Relationship, Farnham, Ashgate, 2011, pp. 24-31, para quien la regla es costumbre, aunque advierte que no hay acuerdo sobre si su cristalización alcanza a todos los crímenes o solo a los más graves. En su opinión existe consenso respecto de los crímenes prohibidos por normas de ius cogens. El carácter obligatorio de la regla aut dedere aut iudicare respecto de estos crímenes de ius cogens también ha sido afirmado por Bassiouni, véase BAssiounI, M. Ch., «Universal jurisdiction for International Crimes: Historical Perspectives and Contemporary Practice», en BAssiounI, M. Ch., International Criminal Law. Vol. II: Multilateral and Bilateral Enforcement Mechanisms, 3. a ed., Leiden, Martinus Nijhoff, 2008, pp. 153-199.

${ }^{41}$ Una posición contraria a la existencia de esta norma consuetudinaria fue la mantenida por cuatro de los jueces que formaron la mayoría que rechazó la solicitud libia de adopción de medidas cautelares en el asunto Lockerbie. Véase la declaración conjunta de los jueces Evensen, Tarassov, Guillaume y Aguilar Mawdsley en el asunto Cuestiones de interpretación y de aplicación de la convención de Montréal de 1971 resultante del incidente aéreo de Lockerbie (Jamahiriya árabe Libia c. Estados Unidos) y Cuestiones de interpretación y de aplicación de la convención de Montreal de 1971 resultante del incidente aéreo de Lockerbie (Jamahiriya árabe Libia c. Reino Unido) (medidas provisionales), CIJ, Recueil, 1992, párr. 2. Frente a ellos, los jueces Weeramantry y Ranjeva, disidentes en la decisión de la Corte que rechazó las medidas cautelares solicitadas por Libia en el asunto Lockerbie, mantuvieron la posición contraria, véase CIJ, Recueil, 1992, pp. 179 y p. 72, párr. 2, respectivamente. Por su parte la jueza ad hoc Ch. van der Wijngaert se pronunció en el mismo sentido en la declaración que hizo respecto de la decisión de 8 de diciembre de 2000 en el asunto Orden de arresto de 11 de abril de 2000 (República Democrática del Congo c. Bélgica) (medidas cautelares), CIJ, Recueil, 2000, pp. 230-231, párr. 6.

42 TPIY, asunto Blaskic, caso núm. IT-95-14, Sentencia de 29 de octubre 1997 relativa a la solicitud de la República de Croacia de examinar la decisión de la Sala de primera instancia II de 18 de julio de 1997, párr. 29.

${ }_{43}$ La Corte entendió que en el momento de la interposición de la demanda no se había evidenciado la existencia de una controversia sobre el incumplimiento por parte de Senegal de obligaciones impues- 
La Sexta Comisión ha debatido sobre esta cuestión en todos los periodos de sesiones de la Asamblea General de Naciones Unidas desde 2006. La falta de acuerdo entre las delegaciones llevó a sugerir a la CDI que estudiara en profundidad esta cuestión ${ }^{44}$, sin embargo, sus conclusiones no han conseguido despejar la duda planteada. En el informe relativo al sexagésimo sexto periodo de sesiones (2014) con el que concluyeron sus trabajos sobre el tema "La obligación de extraditar o juzgar (aut dedere aut judicare)», la Comisión, poniendo de relieve que la incorporación de esta regla en el art. 9 del proyecto de Código de Crímenes contra la paz y la seguridad de la Humanidad (1996) se efectuó con carácter de desarrollo progresivo y teniendo en cuenta las discrepancias mostradas por sus miembros, consideró innecesario pronunciarse sobre esta cuestión ya que su trabajo no iba a adoptar la forma de un proyecto de artículos ${ }^{45}$. Ahora bien, la Comisión aclara que esto no debe interpretarse en el sentido de que «la obligación de extraditar o juzgar no se ha convertido o no está cristalizando aun en una norma de Derecho internacional consuetudinario, sea de carácter general o regional» ${ }^{46}$.

Nos encontramos, por tanto, ante una cuestión necesitada de clarificación y, aunque no cabe descartar que exista o en un futuro termine cristalizando una norma que obligue a los Estados a actuar contra determinados crímenes internacionales cuando el presunto culpable se encuentre en su territorio y ese Estado no conceda la extradición, deberíamos preguntarnos si la misma sería aplicable a cualquier delito o si debería limitarse a los crímenes internacionales más graves y también si su contenido haría primar la obligación de enjuiciamiento o la de la extradición. Mucho ha cambiado la situación relacionada con la represión de los crímenes internacionales más graves en las últimas décadas, y posiblemente también lo haya hecho el carácter de la norma que obliga a extraditar o juzgar a los presuntos responsables de la comisión de un crimen prohibido por una norma de ius cogens y cuyo contenido respondería a la denominada fórmula de La Haya, pero, si pese a todo, se considera que la máxima aut dedere aut iudicare no ha alcanzado el estatus de norma consuetudinaria, ni siquiera en estos casos, lo que parece indiscutible es que los Estados deben cooperar en la represión de estos crímenes; no deben obstaculizar su sanción, lo que implica evitar que su territorio se convierta en refugio de criminales, y no

\footnotetext{
ta por normas de Derecho consuetudinario y que, por tanto, no tenía competencia para pronunciarse sobre las demandas de Bélgica relacionadas con esta cuestión. Véase el asunto Cuestiones relativas a la obligación de perseguir o extraditar (Bélgica c. Senegal), Sentencia de 20 de julio de 2012, CIJ, Recueil, 2012, párrs. 54-55. Posición abiertamente criticada por el juez ad hoc Serge Sur en su opinión disidente, CIJ, Recueil, 2012, p. 610, párrs. 17-18.

${ }^{44}$ Véase Cuarto Informe sobre la obligación de extraditar o juzgar (aut dedere aut judicare) (A/ CN.4/648), pp. 20-21.

${ }_{45}$ La posición de la CDI puede resultar decepcionante si tenemos en cuenta que la Comisión pretendía con su informe ayudar a los Estados en la aplicación de la citada regla y que es precisamente la determinación del carácter consuetudinario o no de la misma lo que suscita dudas y controversia.

${ }^{46}$ Véase Informe de la Comisión de Derecho internacional sobre la labor realizada en su $66 .^{\circ}$ periodo de sesiones (A/69/10), cit., nota 2, pp. 172-173, párrs. 49-54.
} 
pueden rechazar sistemáticamente las solicitudes de extradición o el enjuiciamiento ${ }^{47}$.

\section{LA OBLIGACIÓN AUT DEDERE AUT IUDICARE Y EL DERECHO ESPAÑOL}

\subsection{Las obligaciones derivadas de la regla aut dedere aut iudicare y la regulación prevista en la LOPJ}

En virtud de los compromisos asumidos, nuestro país se ha comprometido a instituir su jurisdicción y reconocer la competencia de sus tribunales para juzgar a los presuntos responsables de haber cometido cualquiera de los crímenes recogidos en los tratados que al regular la obligación aut dedere aut iudicare priman el enjuiciamiento y de los recogidos en tratados en los que dicha obligación queda condicionada a la solicitud de extradición y su posterior denegación.

La competencia de los tribunales españoles para conocer de crímenes de guerra, torturas, desapariciones forzadas, apoderamiento ilícito de aeronaves, los ilícitos contra la seguridad de la aviación civil y los actos de violencia ilícitos cometidos en aeropuertos que presten servicios a la aviación civil, los relacionados con la seguridad de la navegación marítima y de las plataformas fijas situadas en la plataforma continental, los relativos a la protección física de los materiales nucleares, la toma de rehenes, los delitos contra personas internacionalmente protegidas, inclusive los agentes diplomáticos, los perpetrados contra personal de las Naciones Unidas y su personal asociado y los de terrorismo, en particular, el terrorismo con bombas, el nuclear y la financiación del terrorismo, debe contemplar la posibilidad de su enjuiciamiento cuando los presuntos responsables se encuentran en España, ya que nuestro país solo puede liberarse del cumplimiento de la obligación de juzgar si concede su extradición.

Además, también está obligado a establecer su jurisdicción respecto de los delitos recogidos en los convenios internacionales relacionados con el tráfico de drogas, la delincuencia organizada internacional, la corrupción y la venta de niños, la prostitución infantil y la utilización de los niños en la pornografía, cuando el presunto culpable se encuentre en España, haya sido solicitada su extradición y la misma haya sido denegada.

El art. 23 de la LOPJ, al determinar la competencia de los tribunales españoles en el orden penal, además de hacer referencia al principio de territorialidad (art. 23.1), prevé la competencia de nuestros tribunales para conocer de delitos cometidos en el extranjero con arreglo al principio de personalidad

47 En este sentido, véase Abellán Honrubia, V., op. cit., nota 38, p. 245; Abad Castelos, M., La toma de rehenes..., op. cit., nota 38, p. 376, nota 187, y CRYER, R., Prosecuting International..., op. cit., nota 38 , p. 113. 
activa (art. 23.2) y protección (art. 23.3). Junto a ello, el párr. 4 del art. 23, en el que antes se regulaba la competencia de nuestros tribunales para actuar al amparo del principio de universalidad y que tras la reforma efectuada por la Ley Orgánica $1 / 2014^{48}$ ha sido desvirtuado ${ }^{49}$, prevé la competencia de nuestros tribunales para conocer de determinados delitos cometidos fuera del territorio nacional cuando se cumplan las condiciones mencionadas en cada caso.

Entre los delitos enumerados en los distintos apartados del art. 23.4 de la LOPJ se encuentran recogidos los crímenes de guerra, mencionados en el apartado a) bajo la rúbrica de delitos contra las personas y bienes protegidos en caso de conflicto armado ${ }^{50}$; las torturas [apdo. b)] y las desapariciones forzadas [apdo. c) $]^{51}$; los delitos de terrorismo [apdos. d) y e) $]^{52}$; los relacionados con el narcotráfico [apdos. d) e i) ${ }^{53}$; los delitos contra la seguridad de la navegación marítima [apdo. d) ${ }^{54}$; los recogidos en la Convención de La Haya, de 16 de diciembre de 1970, para la represión del apoderamiento ilícito de aeronaves [apdo. f) $]^{55}$; los contenidos en el Convenio de Montreal, de 23

48 Ley Orgánica 1/2014, de 13 de marzo, de modificación de la Ley Orgánica 6/1985, de 1 de julio, del Poder Judicial, relativa a la jurisdicción universal, BOE núm. 63, de 14 de marzo de 2014.

49 Sobre esta reforma véase el Ágora dedicada por el SYIL, en su vol. 18 (2013-2014), con contribuciones de ABad Castelos, M., "The End of Universal Jurisdiction in Spain?», pp. 223-230; CHINCHÓN Álvarez, J., "The Reform(s) of Universal Jurisdiction in Spain: For Whom the Bells Tolls?», pp. 231237; Bollo Arocena, M. D., «The Reform of the Universal Jurisdiction in Spain», pp. 239-247; PÉreZ GonzÁLEZ, C., "Some Comments on Article 24(4) (M) of Spain's Organic Law of the Judiciary: Universal Jurisdiction over Trafficking in Human Beings Offences?», pp. 249-254; EscoBAR HeRnÁNDEZ, C., «Universal Jurisdiction in Spain: Substantial Change of Model or Implied Repeal?», pp. 255-265. El Profesor Sánchez Legido también dedicó su atención a esta reforma, SÁNCHEz LEGIDO, A., "El fin del modelo español de jurisdicción universal», REEI, 2014, núm. 27. Véase también OriHuela CALATAYUD, E., op. cit., nota 6.

50 La competencia de los tribunales españoles queda condicionada a que el procedimiento se dirija contra un español o contra un ciudadano extranjero que resida habitualmente en España, o contra un extranjero que se encontrara en España y cuya extradición hubiera sido denegada por las autoridades españolas.

51 En relación con la tortura y las desapariciones forzadas la competencia de los tribunales españoles queda condicionada a que el procedimiento se dirija contra un español, o la víctima tuviera nacionalidad española en el momento de comisión de los hechos y la persona a la que se impute la comisión del delito se encuentre en territorio español.

52 La competencia de los tribunales españoles respecto de los delitos de terrorismo cometidos en el extranjero varía en función del lugar de comisión de los hechos. Si el delito se comete en espacios marinos, nuestra LOPJ no impone ninguna condición, pero si se cometen en cualquier otro lugar, la competencia de los tribunales españoles queda supeditada a que el supuesto encuentre encaje en los recogidos en el apartado $e$ ).

${ }_{53} \mathrm{Al}$ igual que ocurre con el terrorismo, la competencia de los tribunales españoles para conocer de los delitos relacionados con el tráfico de drogas cometidos en espacios marinos no se encuentra sujeta a ninguna condición adicional, pero en el caso de que se cometan en cualquier otro lugar, la actuación de nuestros tribunales queda limitada a aquellos supuestos en los que el procedimiento se dirija contra un español o cuando se trate de la realización de actos de ejecución de uno de estos delitos o de constitución de un grupo u organización criminal con miras a su comisión en territorio español.

${ }^{54}$ La competencia de los tribunales españoles para conocer de los delitos relacionados con la seguridad de la navegación marítima no está sometida a ningún límite o condición.

55 Según la regulación establecida en este apartado, la actuación contra los responsables de la comisión de estos delitos está condicionada a que el delito se haya cometido por un español o contra una aeronave que navegue bajo pabellón español (sic). 
de septiembre de 1971, para la represión de actos ilícitos contra la seguridad de la aviación civil y su Protocolo complementario, de 24 de febrero de 1988 56; los recogidos en el Convenio, de 3 de marzo de 1980, sobre la protección física de materiales nucleares ${ }^{57}$; algunos relacionados con la delincuencia organizada de carácter transnacional recogidos en el apartado $j)^{58}$; los delitos de corrupción entre particulares y en las transacciones económicas internacionales [apdo. $n$ ) $]^{59}$, y los delitos contra la libertad e indemnidad sexual cometidos sobre víctimas menores de edad [apdo. $k$ ) $]^{60}$. Junto a estos, el apartado $p$ ) del art. 23.4 de la LOPJ contiene una cláusula residual en la que se atribuye competencia a nuestros tribunales para conocer de cualquier otro delito cuya persecución venga impuesta por un tratado vigente para España o por actos normativos de una organización internacional de la que nuestro país sea miembro.

Además en el último inciso del art. 23.4 se establece una cláusula de cierre en la que se prevé la competencia de los tribunales españoles para conocer de delitos cometidos por extranjeros que se encuentren en España cuando su extradición haya sido denegada por las autoridades españolas y su enjuiciamiento venga impuesto por un tratado internacional.

A la hora de determinar si la regulación establecida permite cumplir las obligaciones derivadas de la cláusula aut dedere aut iudicare recogida en los tratados internacionales de los que España es parte, es necesario distinguir tres supuestos. El primero sería el de los delitos no mencionados en el art. 23.4 de la LOPJ; el segundo versa sobre aquellos delitos en los que la obligación de enjuiciamiento está condicionada a un dedere frustrado, y el tercero abarcaría los delitos mencionados en el art. 23.4 de la LOPJ respecto de los que nuestro país ha asumido la obligación de juzgar a los responsables que se hallen en España en el caso de que no se haya recibido una solicitud de extradición o cuando haya sido recibida y se haya denegado.

56 Respecto del enjuiciamiento de estos delitos, la LOPJ no impone ninguna condición.

57 En este caso la competencia de los tribunales españoles queda limitada a aquellos delitos que hayan sido cometidos por un ciudadano español.

58 Según esta disposición, los tribunales españoles son competentes para conocer de los delitos de constitución, financiación o integración en grupo u organización criminal o delitos cometidos en el seno de los mismos, siempre que se trate de grupos u organizaciones que actúen con miras a la comisión en España de un delito que esté castigado con una pena máxima igual o superior a tres años de prisión.

59 En relación con estos delitos los tribunales españoles serán competentes cuando el procedimiento se dirija contra un español o contra un ciudadano extranjero que resida habitualmente en España; el delito hubiera sido cometido por el directivo, administrador, empleado o colaborador de una empresa mercantil, o de una sociedad, asociación, fundación u organización que tenga su sede o domicilio social en España; o el delito hubiera sido cometido por una persona jurídica, empresa, organización, grupos o cualquier otra clase de entidades o agrupaciones de personas que tengan su sede o domicilio social en España.

${ }^{60}$ Nuestros tribunales son competentes para conocer de estos delitos cuando el procedimiento se dirija contra un español o contra un ciudadano extranjero que resida habitualmente en España; el procedimiento se dirija contra una persona jurídica, empresa, organización, grupos o cualquier otra clase de entidades o agrupaciones de personas que tengan su sede o domicilio social en España; o el delito se hubiera cometido contra una víctima que, en el momento de comisión de los hechos, tuviera nacionalidad española o residencia habitual en España. 
Pese a la prolija enumeración efectuada en el art. 23.4, nos encontramos con que existen tres tratados cuyos tipos penales no encuentran cobijo en los recogidos en esta disposición, como es el caso de los enunciados en la Convención de Nueva York, de 14 de diciembre de 1973, sobre la prevención y el castigo de delitos contra personas internacionalmente protegidas, inclusive los agentes diplomáticos ${ }^{61}$, la Convención de Nueva York, de 17 de diciembre de 1979, contra la toma de rehenes y la Convención de las Naciones Unidas, de 9 de diciembre de 1994, sobre seguridad del personal de las Naciones Unidas y del personal asociado ${ }^{62}$. En estos casos la competencia de nuestros tribunales quedaría amparada en el apartado $p$ ) del art. 23.4.

Por lo que respecta a aquellos delitos en los que la obligación de enjuiciamiento está condicionada a un dedere frustrado, el cumplimiento de las obligaciones asumidas por nuestro país queda garantizado ya que, de no encontrar amparo en los apartados correspondientes del art. 23.4, la cláusula de cierre de esta disposición reconoce la competencia de nuestros tribunales para conocer de delitos cometidos fuera del territorio nacional por extranjeros que se encuentren en España y cuya extradición haya sido denegada por las autoridades españolas cuando así lo imponga un tratado vigente para España. Ahora bien, en relación con esta cuestión, es necesario tener en cuenta que nuestro país es parte en el Convenio de Ginebra, de 20 de abril de 1929, sobre la represión de la falsificación de moneda, al que no he hecho referencia por ser anterior a 1945. Este delito figuraba entre los que nuestros jueces podían enjuiciar en España al amparo del principio de universalidad cuando podía considerarse que esta disposición regulaba la jurisdicción universal exclusivamente, pero la reforma del art. 23.4 efectuada por la Ley Orgánica $1 / 2009$, de 3 de noviembre, complementaria de la Ley de reforma de la legislación procesal para la implantación de la nueva oficina judicial, por la que se modifica la Ley Orgánica 6/1985, de 1 de julio, del Poder Judicial ${ }^{63}$,

${ }^{61}$ Convención en la que se hace referencia a: a) la comisión de un homicidio, secuestro u otro atentado contra la integridad física o la libertad de una persona internacionalmente protegida; $b$ ) la comisión de un atentado violento contra los locales oficiales, la residencia particular o los medios de transporte de una persona internacionalmente protegida que pueda poner en peligro su integridad física o su libertad; $c$ ) la amenaza de cometer tal atentado; d) la tentativa de cometer tal atentado, y e) la complicidad en tal atentado.

${ }_{62}$ En la que se consideran delitos contra el personal de las Naciones Unidas y su personal asociado: la comisión intencional de: a) un homicidio, secuestro u otro ataque contra la integridad física o la libertad de cualquier miembro del personal de las Naciones Unidas o el personal asociado; $b$ ) un ataque violento contra los locales oficiales, la residencia privada o los medios de transporte de cualquier miembro del personal de las Naciones Unidas o del personal asociado, que pueda poner en peligro su integridad física o su libertad; c) una amenaza de tal ataque con el objetivo de obligar a una persona natural o jurídica a realizar o abstenerse de realizar algún acto; $d$ ) una tentativa de cometer tal ataque, y e) un acto que constituya la participación como cómplice en tal ataque o tentativa de ataque o que suponga organizar u ordenar a terceros la comisión de tal ataque.

${ }_{63}$ Entre quienes han comentado y valorado la reforma operada por esta ley véase EsTEVE MoLTó, J. E., "Causes and initial effects of the Spanish Organic Law 1/2009 reforming the principle of universal Jurisdiction in Spain», SYIL, 2010, núm. 16, pp. 19-53, y «La aplicación por el Pleno de la Sala de lo Penal de la Audiencia Nacional de los nuevos límites a la jurisdicción universal: un paso hacia la impunidad», REDI, 2010-2, vol. 62, pp. 321-325; FERRER LlORET, J., «The Principle of Universal Criminal Jurisdiction in Spanish Practice (2003-2009)», SYIL, 2009, vol. 15, pp. 63-106; Márquez Carrasco, C. 
suprimió la falsificación de moneda extranjera ${ }^{64}$ del listado. En este caso hay que considerar que la competencia de nuestros tribunales quedará amparada en el apartado $p$ ) y/o en la cláusula de cierre, en la medida en que la referencia que la misma hace a los delitos anteriores hay que entenderla inclusiva de todos los mencionados en los dieciséis apartados del art. 23.4 y, por tanto, también en el apartado $p$ ).

La competencia de los tribunales españoles para conocer de los delitos recogidos en convenios en los que la regla aut dedere aut iudicare prima la obligación de juzgar no encuentra amparo en la cláusula de cierre, pues su redacción no ha tenido en cuenta la diversidad de la regulación internacional y se ha limitado a dar cobertura a las obligaciones derivadas de esta regla cuando la misma prima la obligación de entrega. En estos casos la competencia de nuestros tribunales debería quedar recogida en los apartados correspondientes del art. 23.4 de la LOPJ.

Según las condiciones impuestas a los delitos que nuestro país se encuentra obligado a juzgar, si no concede la extradición, desde el momento en el que se detecta la presencia del presunto responsable en nuestro territorio, existen supuestos en los que la competencia de nuestros tribunales está prevista y, por tanto, se podrán cumplir las obligaciones internacionalmente asumidas, pero también hay otros en los que la regulación no es coherente con las mismas.

Advertida ya la posibilidad de que nuestros tribunales puedan conocer de los delitos de toma de rehenes contra personas internacionalmente protegidas o contra el personal de Naciones Unidas cometidos en el extranjero por un extranjero que se encuentre en España, los supuestos en los que el cumplimiento de la obligación de enjuiciamiento establecida en los tratados está asegurado están relacionados con aquellos delitos para los que no se ha impuesto ninguna condición, como ocurre con los relacionados con la seguridad de la navegación marítima [art. 23.4.d)], o en los que se prevé la actuación de nuestros tribunales en los supuestos autorizados por el tratado, como es el caso de los delitos relacionados con la seguridad de la aviación civil recogidos en el Convenio de Montreal, de 23 de septiembre de 1971, y en el Protocolo de Montreal, de 24 de enero de 1988.

y Martín Martínez, M., «El principio de jurisdicción universal en el ordenamiento jurídico español: pasado, presente y futuro», Anuario Mexicano de Derecho Internacional, 2011, vol. 11, pp. 251-303, y PIGRAU SolÉ, A., La jurisdicción universal y su aplicación en España: La persecución del genocidio, los crímenes de guerra y los crímenes contra la humanidad por los tribunales nacionales, RxDH: Col-leció Recerca per Drets Humans, 03, Barcelona, 2009.

${ }^{64} \mathrm{La}$ referencia a este delito se encontraba en el apartado d) de la Ley Orgánica 6/1985, de 1 de julio, del Poder Judicial (LOPJ) y allí se mantuvo hasta la reforma de 2009. Véase BOE núm. 157, de 2 de julio de 1985; BOE núm. 104, de 1 de mayo de 1999, en el que se publicó la Ley Orgánica 11/1999, de 30 de abril, de modificación del Título VII del Libro II del Código Penal, aprobado por la Ley Orgánica 10/1995, de 23 de noviembre; BOE núm. 163, de 9 de julio de 2005, respecto de la Ley Orgánica 3/2005, de 8 de julio, de modificación de la Ley Orgánica 6/1985, de 1 de julio, del Poder Judicial, y BOE núm. 278, de 20 de noviembre de 2007, en el que se publicó la Ley Orgánica 13/2007, de 19 de noviembre, para la persecución extraterritorial del tráfico ilegal o la inmigración clandestina de personas. Sobre estas reformas, véase ORIHUEla CALATAYUd, E., op. cit., nota 6. 
Sin embargo, en relación con los restantes delitos, el cumplimiento de la obligación establecida en los tratados no está asegurado o resulta imposible. Nuestro país no podrá cumplir la obligación asumida en la Convención de La Haya, de 16 de diciembre de 1970, sobre represión del apoderamiento ilícito de aeronaves, pues el art. 23.4.f) de la LOPJ solo prevé la competencia de nuestros tribunales cuando el delito sea cometido por un español o contra una aeronave que navegue bajo pabellón español, siendo imposible el enjuiciamiento de un extranjero responsable de su comisión y que se halle en España cuando el apoderamiento ilícito se haya cometido contra una aeronave matriculada en cualquier otro Estado. Y lo mismo cabe decir de los delitos recogidos en el Convenio, de 3 de marzo de 1980, sobre protección física de materiales nucleares, ya que la competencia de nuestros tribunales solo está prevista cuando el delito haya sido cometido por un español. En este caso nuestros tribunales carecen de competencia para enjuiciar cualquiera de los actos recogidos en el art. 7.1 del Convenio ${ }^{65}$ cuando sean cometidos en el extranjero y por un extranjero, aunque este se encuentre en España, lo que implica el incumplimiento de la obligación de establecer su jurisdicción cuando el presunto responsable se encuentre en su territorio y no lo extradite y la de enjuiciar recogida en el art. 10 de este tratado.

En relación con el terrorismo, aunque la regulación establecida en esa disposición resulte amplia, es necesario destacar que la competencia de nuestros tribunales está asegurada si el delito se comete en un espacio marino [art. 24.3.d)], pero no siendo así, los límites incorporados en el apartado $e)^{66}$ pueden resultar insuficientes para asegurar el cumplimiento de la obligación de enjuiciamiento recogida en los convenios relacionados con los atentados

65 Según lo establecido en esta disposición, se considera delito la comisión intencionada de: a) un acto que consista en recibir, poseer, usar, transferir, alterar, evacuar o dispensar materiales nucleares sin autorización legal, si tal acto causa, o es probable que cause, la muerte o lesiones graves a una persona o daños materiales sustanciales; $b$ ) hurto o robo de materiales nucleares; $c$ ) malversación de materiales nucleares o su obtención mediante fraude; $d$ ) un acto que consista en la exacción de materiales nucleares mediante amenaza o uso de violencia o mediante cualquier otra forma de intimidación; e) una amenaza de: i) utilizar materiales nucleares para causar la muerte o lesiones graves a una persona o daños materiales sustanciales; ii) cometer uno de los delitos mencionados en el apartado $b$ ) a fin de obligar a una persona física o jurídica, a una organización internacional o a un Estado a hacer algo o abstenerse de hacer algo; $f$ ) una tentativa de cometer uno de los delitos mencionados en los apartados $a$ ), b) o $c$ ), y b) un acto que consista en participar en cualquiera de los delitos mencionados en los apartados $a$ ) a $f$ ).

66 Este apartado, tras la modificación introducida por la Ley Orgánica 2/2015, de 30 de marzo, prevé la competencia de nuestros tribunales en los siguientes supuestos: $1 .^{\circ}$ el procedimiento se dirija contra un español; $2 .^{\circ}$ el procedimiento se dirija contra un extranjero que resida habitualmente o se encuentre en España o, sin reunir esos requisitos, colabore con un español, o con un extranjero que resida o se encuentre en España, para la comisión de un delito de terrorismo; $3 .^{\circ}$ el delito se haya cometido por cuenta de una persona jurídica con domicilio en España; $4 .^{\circ}$ la víctima tuviera nacionalidad española en el momento de comisión de los hechos; $5 .^{\circ}$ el delito haya sido cometido para influir o condicionar de un modo ilícito la actuación de cualquier Autoridad española; $6 .^{\circ}$ el delito haya sido cometido

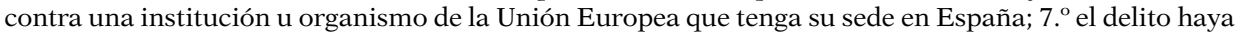
sido cometido contra un buque o aeronave con pabellón español, o $8 .^{\circ}$ el delito se haya cometido contra instalaciones oficiales españolas, incluyendo sus embajadas y consulados. A estos efectos, se entiende por instalación oficial española cualquier instalación permanente o temporal en la que desarrollen sus funciones públicas autoridades o funcionarios públicos españoles. 
terroristas efectuados con bombas, la financiación del terrorismo y el terrorismo nuclear, siendo posible que, si el presunto culpable se encuentra en nuestro territorio y la competencia de los tribunales no queda amparada en los supuestos recogidos en el apartado $e$ ), se incumpla la obligación de enjuiciamiento recogida en la regla aut dedere aut iudicare incluida en esos tres tratados.

Por lo que respecta a la tortura y la desaparición forzada de personas, la regulación establecida en los apartados b) y c) del art. 23.4 de la LOPJ impide a nuestro país cumplir con la obligación de enjuiciamiento que imponen las Convenciones de 1984 y 2006, salvo en aquellos casos en los que la víctima tuviera nacionalidad española en el momento de la comisión de los hechos. Según esta regulación, los tribunales españoles carecen de competencia para conocer de estos delitos cuando se cometen fuera del territorio nacional por extranjeros y contra extranjeros o contra españoles que hubieran adquirido la nacionalidad con posterioridad a la fecha de la comisión de los hechos cuando el presunto culpable se halle en España. Nos encontramos ante una regulación que impide cumplir nuestras obligaciones; abre la puerta a la impunidad de todos los extranjeros responsables de torturas y desapariciones forzadas cuyas víctimas no fueran españolas, y ofrece nuestro territorio como refugio a estos criminales.

En relación con los crímenes de guerra o delitos contra las personas y bienes protegidos en caso de conflicto armado, las únicas posibilidades de actuación de nuestros tribunales están condicionadas a los supuestos en los que el procedimiento se dirija contra un español, contra un ciudadano extranjero que resida habitualmente en España o contra un extranjero que se encontrara en España y cuya extradición hubiera sido denegada por las autoridades españolas. Estando condicionada la competencia de nuestros tribunales sobre los extranjeros responsables de crímenes de guerra que se hallen en nuestro territorio a la solicitud de extradición, nuestra LOPJ impide el cumplimiento de la obligación de enjuiciamiento prevista en los Convenios de Ginebra, de 12 de agosto de 1949, en el Protocolo adicional I a estos, de 8 de junio de 1977 y en el Protocolo II, de 26 de marzo de 1999, de la Convención de La Haya, de 12 de agosto de 1954, sobre la protección de los bienes culturales en caso de conflicto armado. Cabe, por tanto, discrepar de la conclusión extraída por nuestro Tribunal Supremo en su Sentencia de 6 de mayo de 2015 con la que confirma el archivo del caso Tibet decretado por la Audiencia Nacional ${ }^{67}$. Siendo cierto, como advierte el Tribunal Supremo, que la obliga-

${ }^{67}$ En la citada sentencia, el Tribunal Supremo advierte que no se aprecia que la redacción del art. 23.4.a) de la LOPJ vulnere los Convenios de Ginebra (FD 27) y que, según lo establecido en dicha disposición, «los Tribunales españoles carecen de jurisdicción para investigar y enjuiciar delitos contra las personas y bienes protegidos en caso de conflicto armado cometidos en el extranjero, salvo en los supuestos en que el procedimiento se dirija contra un español o contra un ciudadano extranjero que resida habitualmente en España, o contra un extranjero que se encontrara en España y cuya extradición hubiera sido denegada por las autoridades españolas» (FD 29). Una conclusión que hace extensiva a otros procedimientos, lo que ha tenido repercusión en el caso Couso, pues el titular del Juzgado Central de Instrucción núm. 1 de la Audiencia Nacional dictó, el 9 de junio de 2015, auto en aplicación de la 
ción de enjuiciamiento recogida en los Convenios de Ginebra está referida a los Estados en cuyo territorio se encuentre el presunto responsable de la comisión de una infracción grave de los citados convenios ${ }^{68}$, la conclusión sentada sobre la coherencia de nuestra LOPJ con lo establecido en los Convenios de Ginebra no supera un análisis detenido de lo establecido en estos. Nuestro Tribunal no ha tenido en cuenta que la obligación de enjuiciamiento establecida en estos Convenios no está condicionada a la existencia de una solicitud de extradición y a su posterior denegación. De viajar a España un extranjero responsable de la comisión de una infracción grave de los convenios de Ginebra de 1949 o del Protocolo adicional I de 1977 y no formularse contra él ninguna solicitud de extradición, nuestros tribunales carecen de competencia para proceder a su enjuiciamiento y, en este caso, nuestro país estará incumpliendo la obligación de hacerlos comparecer ante sus propios tribunales establecida en los Convenios de Ginebra ${ }^{69}$.

\subsection{Propuestas de mejora que eviten el incumplimiento de la obligación aut dedere aut iudicare}

Las insuficiencias que presenta el art. 23.4 de la LOPJ para hacer efectivo el cumplimiento de todas las obligaciones derivadas de la regla aut dedere aut iudicare recogida en convenios en los que España es parte deben ser suprimidas. Necesitamos una regulación que se ajuste a todos nuestros compromisos internacionales o, de ser posible, unas obligaciones internacionales que sean conformes con nuestro Derecho interno. Para conseguirlo cabe imaginar varias hipótesis.

Con la finalidad de que nuestro país ajuste sus compromisos internacionales a la regulación establecida en el art. 23.4 de la LOPJ, cabría pensar, en primer lugar, en la denuncia de los tratados cuyas obligaciones no puedan ser cumplidas, así como en renunciar a participar en futuros convenios internacionales destinados a la prevención y sanción de crímenes internacionales, como puede ocurrir con los de lesa humanidad, cuando obliguen a los Estados partes a enjuiciar a los presuntos responsables que se encuentren en su territorio. Ahora bien, la primera de las opciones planteadas - denuncia de tratados - puede quedar descartada respecto de algunos convenios ${ }^{70} \mathrm{y}$, por

doctrina sentada por el Tribunal Supremo declarando concluso el sumario y su remisión a la Sala de lo Penal de la Audiencia Nacional (Auto de 9 de junio de 2015, Juzgado Central de Instrucción núm. 1, AN, Sumario 27/2007).

68 FD 27.

69 Obligación contenida en los arts. 49, 50, 129 y 146 de los Convenios de Ginebra I, II, III y IV, respectivamente.

${ }_{70}$ Como puede ser el caso de los convenios relacionados con la protección de los derechos humanos y el Derecho internacional humanitario, pues la denuncia no motivada de los mismos con arreglo al art. 56 de la Convención de Viena sobre Derecho de los tratados, de 23 de mayo de 1969, $B O E$ núm. 142, de 13 de junio de 1980, puede encontrar oposición por alguna de las partes en los doce meses siguientes a su notificación al resto de partes. Además, no debemos olvidar que ya existen pronunciamientos de los órganos de vigilancia de algunos de ellos sobre la inadmisibilidad de denuncias 
tanto, es posible que solo resulte viable en relación con el Convenio de La Haya, de 16 de diciembre de 1970, sobre represión del apoderamiento ilícito de aeronaves; la Convención de Viena, de 3 de marzo de 1980, sobre protección física de los materiales nucleares; la Convención de las Naciones Unidas, de 15 de diciembre de 1997, para la represión de los atentados terroristas con bombas; el Convenio de Nueva York, de 9 de diciembre de 1999, para la represión de la financiación del terrorismo y la Convención, de 13 de abril de 2005, para la supresión de actos de terrorismo nuclear. En segundo lugar, cabría pensar en la posibilidad de presentar reservas tardías a través de las cuales se modifiquen las disposiciones que resultan incompatibles con nuestra legislación. La finalidad de estas reservas consistiría en condicionar el nacimiento de la obligación de juzgar a la presentación y denegación de una solicitud de extradición. La viabilidad de las mismas no está asegurada, ya que, al menos en la práctica de Naciones Unidas, su formulación se admite a condición de su aceptación unánime y, si tenemos en cuenta que las reservas que habría que formular afectan directamente al objeto y fin de estos convenios, es de esperar alguna reacción contraria a las mismas.

Las dificultades que presentan estas propuestas y el perjuicio que sin duda ocasionaran a la imagen pública de nuestro país hacen que la única posibilidad sea la de ajustar la regulación española a nuestros compromisos internacionales, lo que hace imprescindible una modificación del art. 23 de la LOPJ. Para conseguir que nuestro país pudiera cumplir todas sus obligaciones internacionales derivadas de la obligación aut dedere aut iudicare bastaría con que nuestro art. 23 de la LOPJ reconociera la competencia de los tribunales españoles para conocer de los delitos cometidos fuera del territorio nacional por ciudadanos extranjeros que se encontraran en España siempre que así lo imponga un tratado internacional o un acto normativo de una organización internacional de la que nuestro país sea miembro. Dicha competencia podría incluirse en un apartado nuevo del art. 23 y con ello nuestro país no tendría por qué amparar estas actuaciones en el principio de universalidad. Si junto a ello se incluyera la competencia de nuestros tribunales para conocer de determinados delitos cuando la víctima sea española siempre que así lo imponga un tratado internacional o un acto normativo de una organización internacional, el actual art. 23.4 de la LOPJ y el reconocimiento de la jurisdicción universal en España resultarían innecesarios. Actualmente el reconocimiento y ejercicio de la jurisdicción universal resulta imprescindible porque nuestro país no tiene incorporado el reconocimiento de la competencia de los tribunales españoles para actuar sobre la base del principio de personalidad pasiva y ser parte en Convenios Europeos que imponen el establecimiento de la jurisdicción, ni en la condición de iudex aprehensionis que permitiría el cumplimiento de la obligación derivada de la regla aut dedere aut iudicare y el enjuiciamiento de la piratería. Si estas incorporaciones al art. 23.4 se hicieran, España no necesitaría regular la jurisdicción universal para el estricto

en aplicación de las cláusulas convencionales que las habían previsto. En este sentido, véase REMIRO Brotons, A., op. cit., nota 5, p. 323. 
cumplimiento de las obligaciones internacionales ${ }^{71}$. ¿Era esta la intención de nuestro legislador cuando acometió la reforma de 2014? Evidentemente no ${ }^{72}$.

En el caso de que nuestro legislador quiera seguir haciendo uso del principio de universalidad para el cumplimiento de las obligaciones derivadas de la regla aut dedere aut iudicare, debería modificarse el art. 23.4 de la LOPJ para prever en el apartado $a$ ) la competencia de los tribunales españoles respecto de los crímenes de guerra cuando los presuntos culpables se encuentren en nuestro territorio; para excluir de los apartados $b$ ) y $c$ ), relacionados con la tortura y las desapariciones forzadas, la exigencia de víctimas españolas, y para incluir en los apartados e), f) y h) la competencia de nuestros tribunales cuando el presunto culpable se halle en nuestro territorio y no se proceda a su extradición de conformidad con lo previsto en los tratados internacionales.

\section{CONCLUSIÓN}

El reconocimiento de la competencia de los tribunales estatales para enjuiciar hechos cometidos fuera del territorio nacional debe ser conforme con las obligaciones derivadas de la participación en tratados internacionales destinados a la prevención y sanción de crímenes internacionales o delitos de trascendencia internacional.

Muchos de estos tratados imponen a las partes la obligación aut dedere aut iudicare primando el enjuiciamiento de los presuntos responsables que se hallen en su territorio y en los que la extradición es solo una vía para eludir su cumplimiento y, por tanto, la participación en ellos obliga a reconocer la competencia de los tribunales estatales para enjuiciar esos delitos desde el momento en el que se conoce la presencia del presunto responsable en su territorio.

En nuestro país, el cumplimiento de estas obligaciones se ha efectuado generalmente a través de la actuación de los tribunales españoles al amparo de la jurisdicción universal. Los deseos de evitar los problemas que esta jurisdicción universal ha planteado en las relaciones diplomáticas y las dificultades que imprimían a los intereses de nuestro Gobierno han llevado a nuestros políticos a establecer una regulación que hiciera desaparecer dichos problemas y dificultades.

Restringir el ejercicio de la jurisdicción universal al estricto cumplimiento de las obligaciones internacionales es una opción política regresiva, pero legítima. Ahora bien, al hacerlo ha de establecerse una regulación coherente con nuestras obligaciones internacionales y eso es lo que la reforma establecida por la Ley Orgánica 1/2014 no ha conseguido.

71 Esta era la razón que según el legislador motivó la reforma de 2014. Véase la exposición de motivos de la Ley 1/2014, de 13 de marzo, BOE núm. 63, de 14 de marzo de 2014.

${ }^{72}$ En mi Discurso de incorporación como Académica de Número de la Real Academia de Legislación y Jurisprudencia de la región de Murcia, op. cit., nota 6, pp. 160-167, se pueden consultar los motivos que me llevan a una valoración negativa de la reforma operada en 2014. 


\title{
RESUMEN
}

\section{LA OBLIGACIÓN AUT DEDERE AUT IUDICARE Y SU CUMPLIMIENTO EN ESPAÑA}

El cumplimiento de la obligación aut dedere aut iudicare impone a los Estados el reconocimiento de la competencia de sus tribunales para juzgar hechos ocurridos fuera del territorio nacional cuando los responsables de su comisión se encuentren en su país. Tomando como elementos de análisis los tratados multilaterales generales de los que España es parte que contienen dicha obligación, este trabajo evalúa el carácter y alcance de las mismas y determina si su cumplimiento es posible en virtud de la regulación establecida en la LOPJ. La constatación de sus insuficiencias ha determinado la concreción de propuestas de mejora que las eliminen.

Palabras clave: jurisdicción penal, aut dedere aut iudicare, competencia de los tribunales españoles.

\begin{abstract}
THE AUT DEDERE AUT IUDICARE OBLIGATION AND ITS FULFILLMENT IN SPAIN

In order to fulfill their aut dedere aut judicare obligation, States must recognize the competence of their courts to prosecute events happening outside their territory, when the alleged responsible for their commission are found in his/her country. Considering as elements for a general analysis general multilateral treaties of which Spain is a contracting party, this paper aims at assessing the nature and scope of this obligation so as to determine if this kind of compliance is possible under the LOPJ (Spanish Law regulating the judiciary power). Finally, the present work comes up with several suggestions for the overall improvement of the situation and in order to avoid inconsistencies.
\end{abstract}

Keywords: criminal jurisdiction, aut dedere aut iudicare, spanish courts competence. 